\title{
Why Does Political Science Hate American Indians?
}

\author{
Kennan Ferguson
}

\begin{abstract}
Native Americans have been structurally excluded from the discipline of political science in the continental United States, as has Native epistemology and political issues. I analyze the reasons for these erasures and elisions, noting the combined effects of rejecting Native scholars, political issues, analysis, and texts. I describe how these arise from presumptions inherent to the disciplinary practices of U.S. political science, and suggest a set of alternative formulations that could expand our understanding of politics, including attention to other forms of law, constitutions, relationships to the environment, sovereignty, collective decision-making, U.S. history, and majoritarianism.
\end{abstract}

N ative Americans are missing from political science. ${ }^{1}$ Or, more accurately, the formations of political science as a discipline have erased Native identity, Native philosophy, and Native history from its areas of concern.

This lack arises not from mere ignorance but from a deliberate avoidance of Native claims within mainland U.S. political science. Indigenous patterns of thought overtly oppose many of the values that United States presumes: the legitimacy of majoritarian democracy, the primacy of sovereignty, the rule of law, and especially American exceptionalism. Attention to other forms of law, constitutions, relationships to the environment, nationalism, collective decision-making, and sovereign status would greatly expand the conceptual resources available to political science as a discipline.

Erasures and elisions concerning American indigeneity within political thought infect political science in ways

Kennan Ferguson teaches political theory at the University of Wisconsin-Milwaukee, where he also directs the Center for 21st CenturyStudies (kennan@uwm.edu). He is the author of All in the Family: On Community and Incommensurability; Willliam James: Politics in the Pluriverse; and The Politics of Judgment. He coedits Theory \& Event and the book series Modernity and Political Thought. This project would not have been possible without many conversations with a great many politically-minded Native scholars, activists, curators, and community leaders. The author would like to thank all of them. A number of colleagues, too, have been invaluable: Cary Miller, Carolyn Eichner, Katherine Paugh, Kristin Pitt, Jennifer

London, Carolyn Seymour-Jorn, David Temin, Deborah Wilk, Bernard Perley, and Kimberly Blaeser. parallel (but not identical) to the discipline's relationship to international colonialism. Core aspects of various subdisciplines of political science have been built around the subjugation of different peoples. In the mid-twentieth century, the study of politics was forced to recognize its previous exclusion of a large portion of the world's population, peoples who had been obscured in the predominant conceptions of colonial power and imperial representation. Decolonization not only changed the world's ordering, but also highlighted the various ways in which political science had justified and rationalized those systems of domination and oppression. Now, in the twenty-first century, it is time for political science as an epistemological organization to recognize and remedy its current exclusion of the peoples of the land on which we live.

Even as comparative politics has begun to consider indigenous non-state actors and issues, and as comparative political theory has emerged as a subfield of political theory, the disciplinary facade of political science remains mostly intact. Each of these developments pose conceptual challenges to the Western presumptions of political philosophy, and these two approaches have the potential to link to one another. But attention to American Native issues still drops out. Comparative politics by definition casts it eyes beyond the boundaries of the United States. It regards Native North American politics as too domestic, too constrained by history, not "civilizational" enough. Native politics, though they emerge from historical nations with clear treaty relationships with the United States, thus seem to have no claim on comparative politics. Comparative political theory, too, looks beyond the boundaries our own settler colonial past. It ignores Native epistemologies and theories, even when these nations had well-developed traditions of governance and concepts of collectivity, some 
of which influenced the authors of the U.S. Constitution. (Interestingly, this absence does not occur in Canada nor in Alaska or Hawai $i$, all of which have paid attention to regional indigenous political theory).

Three important points: First, my target audience is not Native Americans or even Native scholars, but rather political scientists. Various structural forces have kept Natives out of certain areas of the academy. The implications are not that Indians need to learn or change their interests and studies, but that political science is long overdue for a serious analysis of the racial, cultural, and civilizational presumptions that exclude Native thought and experience. Second, these analyses pertain mostly to the current era, and apply only to the state of the discipline as it is currently constituted through its organizational and institutional structures (i.e., what counts as serious areas of study, what presumptions are baked into the categories comprising political action, and what is currently recognized as "true social science"). Third, I present my conclusions as provisional and partial. My own areas of interest and training clearly limit my observations, which thus remain partial and blinkered. It is not impossible that there exists a thriving network of Native scholars in comparative politics who deal with Native nations as seriously as they do China or Russia, backed by a dense node of universities whose political science departments have put indigenous thought and history on a par with European thinkers and events. But I have found no evidence of such a community.

\section{Who Counts?}

Four observations: ${ }^{2}$

- Very few members of political science departments in the continental United States are Native Americans.

- Very few Native issues are seen by U.S. political scientists as being of central political importance.

- Very few Native viewpoints and analyses are considered critical within political science in the United States.

- Very few Native intellectuals' and scholars' texts and speeches are taught in U.S. political science courses.

Why is this? In truth, even though each concerns political science in the continental United States, these are four very different issues. ${ }^{3}$ Whereas one emerges from intellectual history and influence, another has more to do with the makeup of the canon of political science. For example, the first observation does not necessarily connect to any of the others; identity does not equal correlative interest. A Diné political scientist might be interested in European Union organization or the Japanese National Diet. So none of these issues necessitate any of the others.
In practice, however, these absences reinforce one another. Together, they allow the discipline of political science to participate in practices of exclusion and forgetfulness that ultimately ignore Native politics, to the detriment of American indigenes and the discipline alike. Without a conceptual history of eliminationist policies, we misunderstand American practices and ideologies. Without the presence of Native academics, we ignore alternative conceptions and critiques of political identities. Without consideration of local and autochthonous epistemologies, we miscount and miscredit forms of political action. The lack of any of these people or perspectives makes ignoring the others much easier.

Even once it becomes clear whose interests these various absences serve-viz., the colonial system of settlement - the techniques and procedures of exclusion involved may seem opaque or even organic. This is because they remain institutionally naturalized. Each individual political science department, for example, has its own needs and concerns, battling over resources, grants, students, and legitimacy. Each has its own strengths and weaknesses, conceptual trajectories, historical affiliations. Each, therefore, has its own claims about why it, specifically, has never hired an American Indian scholar. Many of these excuses ring familiar: that isn't our departmental focus; not enough graduate applications enter our program with an interest in those topics; no Native scholars meeting the minimum qualifications applied for the last job we advertised.

But the constant repetition of absence across so many departments should demand critical examination. Social science prides itself on identifying structures not immediately visible to actors and decision-makers themselves. So why do departments of English, history, education, and even anthropology in the United States have sizable (though still insufficient and unrepresentative) populations of Native scholars, and political science does not?

In 1999, Vine Deloria Jr. and David Wilkins, among the preeminent Native American scholars in the academy, argued that political science presented an ideal home for Native Studies. "Unlike its sister sciences of anthropology, sociology, and psychology," they held, "political science, at least in the United States, has less of the continuing odor of colonial arrogance that infects the concepts and academic establishment of the above-mentioned social science." The norms and histories of other social scientific disciplines omitted Native viewpoints and American Indians from their respective canons, Deloria and Wilkins concluded, but the empirical and politicized outlook of political science, especially the centrality of law, sovereignty, and the attention to the particularity of racial and ethnic minoritarianism, made it a promising location to engage Native claims. 
The past generation of political science, however, has not borne out their optimism. ${ }^{5}$ This is largely because their concerns about the discipline's focus have remained unheeded. Deloria and Wilkins warned that "the concern with formal institutions and the corresponding measurement of attitudes regarding these institution" would prove radically insufficient to understand the wide ontological and epistemological contributions that indigenous Americans could bring to the study of politics and power. ${ }^{6}$ Rather than taking on the substantive presumptions that have been necessary in supporting settler colonialism, the discipline has instead frequently retreated to technical questions of method and statistical analysis that unproblematically assume the primacy of the nation-state, the legitimacy of American constitutionalism, and the normative justice of colonialism. Rather than noting settlement's complex linkages between history, intellectual recognition, representation, and policy/political issues, political science continues to reinforce them, itself ignoring Indian histories and claims.

Nor were Deloria and Wilkins correct in their analysis of political science's history. The state of the academic world during the discipline's emergence at the end of the nineteenth century consisted of a morass of racial hierarchies, civilizational categorization, and normative settlement. Political science readily participated in the settler colonial presumptions of Indian inferiority and disappearance when confronted with white superiority and triumphalism by depending on the science of biology still committed to hierarchical classification, on an idea of civics still engaged in practices of phrenology and eugenics, and on a teleological model of history that denied the coevalness of non-European peoples. ${ }^{7}$ Most of these presumptions have not changed, even in the face of Native survivance. ${ }^{8}$ Our particular social science, in other words, denies its own social history while asserting its strictly scientific mensurations.

Native experience and lifeworlds emerge from their own understandings of power and knowledge, ones that explain and explore political interactions in North American better than sterile models of state power. Their inclusion has the potential to transform the study of politics. But before analyzing these possibilities, it is important to describe the structural dynamics that continue to obviate Native perspectives for the field. That is, given the four absences with which this section began, what explains them? Why do Native voices and experiences matter so little in political science? What are the individual and structural forces that have kept the discipline European, colonial, white, and exclusionary?

\section{The Process of Elimination}

These are not necessary exclusions. Outside of the continental United States, indigenous peoples can (and do) have a central place in political science, where the integration of indigeneity in its various forms is no longer on the territorial and conceptual margins of political science. A number of political science departments in Canadian universities, especially the University of British Columbia and the University of Victoria (both located on land never ceded to the Canadian government by the resident First Nations) have recently begun to focus on issues of politics in First Nations experiences and settler colonialism. Scholars such as Taiaiake Alfred, Jeff Corntassel, and Heidi Kiiwetinepinesiik Stark (at Victoria) and Glen Coulthard and Sherryl Lightfoot (at UBC) have profoundly indigenized their region's study of politics, and have made their programs pedagogical and scholarly centers of First Nations scholarship. At the University of Hawai i, Noenoe Silva, Hokulani Aikau, and Noelani Goodyear-Ka'opua imbue the department of political science with attention to Native Hawaiian issues, recognizing that the overthrow and occupation of the Hawaiian islands by the U S. government, and the subsequent treatment of Native Hawaiians, underpins politics not only in Hawai' $i$ but also throughout the Pacific. In each of these locations, it is difficult for any student to pass through these programs without an understanding of the complex histories of indigenous peoples and the dominant state power. The presence of these scholars, and their diverse areas of focus, allow and encourage not only graduate students but also undergraduates, fellow faculty, and the local Native populations to see political science as encouraging critical perspectives.

Given the existence and flourishing of these programs, why does mainland United States political science remain so resistant to Native scholarship? In political theory, for example, I am aware of only three Native scholars here: Dartmouth's influential Dale Turner (a full professor), the University of Northern Arizona's Michael Lermer, and the University of San Francisco's Kouslaa Kessler-Mata (both assistant professors). How can entire state systems (California, for example, with nine University of California campuses and twenty-three California State campuses) have not a single American Indian scholar in their political science departments? Clearly, some sets of forces keep indigenous scholars outside of political science.

What are they? I offer the following eight diagnoses strictly as suggestions, open to reinterpretation and analysis. These are not meant to be determinative, but rather to provoke a discussion of other possible structural and historical practices of exclusion. Together, they only begin to answer the question posed by this essay's title.

First and foremost, the discipline of political science is structured around a presumption of nation-states, a set of theoretical predeterminations which excludes the victims of settler colonialism from consideration. With the state as primary unit of analysis, substate and nonstate actorseven those with sovereign power-disappear from consideration. The analytical tools of political science correlate 
closely with a model of absolute governmentality, regardless of whether they concern comparative politics, international relations, or domestic American politics. Institutions build around the state as a gravitational center, and political interests and ideas are continually conflated with states. Indigenous peoples fall outside of these categories; having been, for example, only recently recognized by the United Nations as having potentially different interests from the states that claim to represent them. ${ }^{\text {? }}$

Second, political science suffers from an anti-historical bias. It is profoundly future-oriented, generally using the past only as an empirical set from which to determine future possibilities. Like other aspirational "sciences" such as economics, most practitioners measure themselves by their predictive capacity. Historical events thus become mere repositories of information and patterns, ones that must be approached with suspicion. Because of this intrinsic anti-historicism, the central questions of political science tend to focus on the future and present, such as the growth or change in parties, in voting behavior, or in political movements. The present becomes normative and ethical. Even the limited recognition of past events becomes fodder for a teleology of progress. Political science's history is Whig historicism, the rendition of past events as telling a procedural tale of increasing wealth, happiness, and equality.

Third, interest group politics remains the default model in the study of U.S. power. Indians are therefore seen not as nations with their own modes of legitimacy, but rather are presumed to be one minor interest group among many. Their legal and historical collective identities become mere "ethnicity." Coalitions count; independent polities don't. This is reinforced by prominent anti-Native associations in the general American populace. A social discourse which sees Indians as "getting away with" rights that other citizens do not have, or as claiming more land than their percentage of the population "should" allow, ignores the particularity and historicity of Native claims and legal contestations. Needless to say, many individual political scientists share these unfortunate presumptions. When majoritarianism rules, and coalitional politics are the only ones recognized, Indians lose.

Fourth, law concretizes politics. Political science too often conflates legality with legitimacy and accuracy. Power and law mutually reinforce one another, and the study of power and politics too rarely recognizes the implications of this organization. The processes and procedures of the U.S. Supreme Court have been, in large part, the post facto rationalizations of illegal and unjust land grabs. When it comes to Native people and places, U.S. law disregards land claims, dismisses due process, and forecloses standing. Law is the voice of the settler state, not of the people being displaced and dismissed. The history of treaties, which should be as central to the foundations of international law as is the history of warfare, fares poorly and as a consequence remains mostly ignored. Exceptions to these generalizations exist in a few locations within political science. Most notably, there are a number of Native scholars who study tribal law, whether within the confines of a particular Indian nation (e.g., the legal implications of the current Constitution of the Cherokee Nation of Oklahoma), between the sovereign powers of federally-recognized Native nations and those of the United States government, and within those tribal collectivities which either resist or are denied federallyrecognized status. But these exceptions are few and far between, and impose very little on the presumptions of law and legal study.

Fifth, even those subdisciplines of political science open to the possibilities of Native approaches to politicspolitical philosophy being the primary example-embed presumptions of European superiority. Forget for a moment the close ties between the central figures of modern political thought and the delegitimation of American Indians: Hobbes's claim that no sovereigns exist in the Americas, or Locke's statement that land is not properly utilized by Indians and is thus available for appropriation. ${ }^{10}$ Forget too, that these same figures and many more through the twentieth century ignored the forms of politics and political ideas already extant in the Americas. Instead, note how even the documentary foundations of political theory discredit Native thought. Speeches, treaties, and published narratives appear throughout the historical record, and are well recognized by historians, but are largely ignored in the literature of political concepts. ${ }^{11}$ The presumption of textuality-that only a certain kind of literacy counts as a central or exclusive source of political action - underpins political theory. Material and representational history are ignored: wampum belts, which have clear and widely accepted analytic histories, do not appear as documents for political study. Components of political thoery simply do not include non-textual aspects or components of political thought.

Sixth, the very categories presumed to be political transpose very poorly onto traditional Native practices and experiences. The idea of sovereignty, for example, emerges from customs of kingly rule, not of chieftaincy. An organization such as the League of Five Nations (also known as the Iroquois Confederacy), with fifty co-equal representatives reaching modes of consensus, translates poorly into the language of a political decisionism (even if it arguably modeled a working and effective deliberative body for those writing the 1754 Albany Plan of Union and the U.S. Constitution). ${ }^{12}$ And these ambiguities were widely exploited by colonizers, increasing the difficulty of analysis. Examples abound of white settlers deciding that one tribal member rather than another was the true sovereign (naming someone the "Chief"), and thus able to alienate tribal lands. ${ }^{13}$ Today's political issues and events specific to Native communities continue to remain 
obscure to the gatekeepers of the discipline of political science. Debates over language and leadership, the complexities of blood quantum, matrilineality versus patrilineality, economic development's relationship to disenrollment: all remain poorly understood by political scientists, including those living mere miles from the lands of these debates. Even the basic metrics of left and right, or Democrat and Republican, do not map neatly onto Indian affairs. The twentieth century saw both Franklin Delano Roosevelt passing the "Indian New Deal," which restored mineral rights to Native peoples, and Richard Nixon ending the widely censured process of "termination," the systematic destruction of tribal sovereignty in the name of assimilation. Continuing traditional cultural practices and defending natural resources can be conceptualized as conservative or as progressive, depending on the metrics.

Seventh, just as the state constitutes the default locale in contemporary political science, the liberal individual stands as the presumed primary opposition to the state, with liberation and liberatory ideals the goal. Note the prevalence in political science of "resistance" and "liberation" as the uncritical paragons of political action; where does such celebration leave the integrative membership of historical and legal collectivities? These assumptions delegitimize communal identity. The presumptions of liberal individualism have long been used to undermine tribal authority-land legally attributed to one person to administer or sell as he or she sees fit alienates collective rights or responsibilities. Inasmuch as academic scholarship presumes individualism as the normative aspiration for political actors, it participates in the termination of tribal self-governance.

Eighth and finally, the structure of institutional academia itself excludes scholarship connected to indigeneity. Professors and graduate students are assumed to be liberal individuals, disconnected from networks of community and alienated from place. It is widely expected that a student will move in a trajectory from an undergraduate degree in one part of the country to graduate work in another (perhaps even with an M.A. and a Ph.D from different instutitions), and will graduate into a first job elsewhere. This necessarily excludes those with profound commitments to place, to family, and to cultural practice, who are unable or unwilling to dissociate their connections for the sake of higher education. While some develop translocal identities, others reject a life lived profoundly distant from their community. ${ }^{14}$ On top of this, the location of many Native students is deeply connected to spaces far from the presumptive networks of academia: the physical location of most reservations, for example, lay far from the capitals of the American academy. Thus certain aspects of Native epistemology -importance of place, connection to land, continuity of community-face inherent devaluation from many of higher education's institutional practices.

\section{Indigenizing Political Science}

Given these structural and conceptual impediments to the location of Native Americans in the discipline, what potential changes could be implemented to reshape political science to actively engage with Native issues and ontologies? It is easy enough to add a Native author to a syllabus or to consider a data set from a reservation rather than an urban city, but such efforts merely keep disciplinary forms unchanged while including one more category of analyis: "add Indians and stir." This is insufficient, and does little to transform the deep structural dynamics which exclude Native politics and academics. Yet the conceptual categorizations of the discipline that focus on polities, politics, and power continue to be extremely important, even vital, for understanding the relationships between and within Native communities and the outside world. The remainder of this essay suggests a few possibilities from within the traditional categories of political science, but which encourage and draw upon the indivisible categories of Native history, epistemology, and power.

How can we, Native and non-Native scholars alike, indigenize the study of political science? Must it first be decolonized, or does one project need to take priority over the other? What methodological, cognitive, and organizational changes should be made? How would such ontological changes exceed mere "cultural learning" into the realm of disciplinary transformations? ${ }^{15}$ Examples could include the following: ${ }^{16}$

A. The recognition of the centrality of Native presence in the history and practice of American government. From the influence of the Iroquois Confederation to the early practices of federalism to the continuing models of law and legitimacy, the institutions of Indian peoples have been the subject — often literally — of U.S. politics. The elision of that history in both its past and present forms can be overcome by squarely centering the colonial practices of the United States in our analyses of the American polity.

B. The reconfiguration of the study of American politics around treaties, which prove equally as important to the structure of government as voting and warfare, topics usually far more closely and deeply covered in political science. Native nations were not the only treaty signatories with the early United States, but they were certainly the most important. Without the study of the status and history of treaties, it is impossible to understand the different relationships between the U.S. government and various Native nations, contemporary U.S. 
obligations to Native peoples, or even North America's history of land ownership. (Another sign of the failure of politics to engage with the realities of Native nations: the U.S. State Department does not list treaties with North American indigenous nations, even those still in force and which the U.S. government is obligated to enforce under international law, in its biannual publication of treaties. $)^{17}$

C. The reconsideration of sovereignty as the critical marker of political systems. The empirical reality of sovereignty, both in the nation-state system and in the case of indigenous peoples, highlights its contradictions and conditionalities. Though theorists such as Foucault and Agamben have made such arguments in the European-historical context, there is little reason to privilege their critiques over the immediate and autochthonal evidence in our own backyards_especially given the extensive legal, theoretical, and historical-evidentiary trail to which we have access. Sovereignty exists partly as a rhetoric, partly as a legalism dependent upon other entities, partly as an immanent claim, and partly as a negotiated politics. A serious study of Native American political experience highlights these truths about sovereignty in ways that international relations often obscures.

D. A reordering of our default units of analysis. Nations should be presumed as the objects of study rather than states. Though this affects all of political science, the subdiciplinces of comparative politics and international relations need to be reconfigured to recognize the realities of Native peoples. In general, only the nation-states acknowledged as UN members are assumed to be legitimate locations for political action; even the recent recognition of non-governmental organizations as serious actors within international politics continues to exclude Native American tribal authorities, which are after all governments. Nations that exist in different recognized spaces actually make up the majority of political actors in the world (compare 193 member states in the United Nations to at least 566 "recognized and eligible" nations located in whole or in part in the United States alone).

E. Attending to the centrality of Natives in American law and jurisprudence. In its first decades, the Supreme Court organized its docket around Indian removal, the dissolution of Native land claims, and negotiating claims of national sovereignty. But while most studies of American constitutional history briefly refer to cases such as Worcester v. Georgia, they generally emphasize issues such as the limits of jurisdictional power. What would it look like to recognize the emergence of U.S. constitutional law as essentially a process of settler colonialism? While many contemporary historians read legal history in this way, such insights remain neglected in political science legal textbooks and syllabi. American law was formed in relation to Native nations; it needs to be taught and conceptualized as such.

F. Recognizing Indian law's equivalence to state and federal constitutionalism. Sovereign tribal authorities form alternative sets of legal rules and regulations; noting this would allow both scholars and students to see the empirical legal pluralism at work in the United States. Complete coverage would be impossible, as over 330 recognized nations exist within the boundaries of the continental United States. But a department which purports to research and teach American law while neither noting its limitations and externalities nor analyzing the multiple varieties of legal systems within its borders does a profound disservice to the complexities of law in the United States. ${ }^{18}$

G. Attention to the emergent and created nature of constitutional law, following the repeated and highly contested writing on American Indian constitutions. The writing of the White Earth Nation's constitution, leading up to its ratification in 2009 and referendum in 2013, vividly shows the political stakes in constitutional writing, approving, and distribution, especially as it continues to be contested by the Minnesota Chippewa Tribe. ${ }^{19}$ Such a process illuminates not only the situation of White Earth, but of the literary and textual nature of all constitutions.

H. A recognition of the extensive history of Native treatments of power and politics in land now claimed by the United States. From Samson Occom to post-Revolutionary War authors such as William Apess to early-twentieth century writers such as Zitkala-Sa and Charles Eastman to the recent work of Vine Deloria Jr., Indian authors have been theorizing law and power in North America for longer than the United States has existed. ${ }^{20}$

I. An acceptance of the importance of work by contemporary Native scholars. Political theorists throughout North America, including Taiaiake Alfred, Dale Turner, Jodi Byrd, and Glen Coulthard, are each transforming both Indigenous Studies and Native American thought. ${ }^{21}$ The legal scholar David Wilkins has done more than anyone else in political science to argue for the importance of Indian law and treaty to the contemporary United States. ${ }^{22}$ A political science that purports to speak on issues such as justice, law, empire, and representation cannot continue to ignore these authors as central to politics. 
J. The establishment of a quasi-canonical set of texts, traditions, and concerns within disciplinary and subdisciplinary aspects of political science and government. This should include the books mentioned, of course, but also work by non-political scientists such as Gerald Vizenor, Audra Simpson, and Joanne Barker. ${ }^{23}$ It might also include theoretical work by scholars who do not identify as Native but base their theoretical perspectives on Native political thought and experience, such as Kevin Bruyneel and Alyosha Goldstein. ${ }^{24}$ Some would dispute the importance of a core set of readings, since the until-recently accepted canon of political theory has been exactly what has excluded Native thought. But the creation of a Native canon would provide a set of concerns, concepts, analyses, and contentions that provide a background for fundamental conversations (and against which new concepts and critiques can evolve).

$K$. The development of an expansive notion of politics away from a purely textual mode. As previously mentioned, a multiplicity of political agreements and representations exist in a wide variety of media, from wampum belts to pictographic images of clan relationships and identities. The inability of political inquiry to consider representational forms other than voting and indited English publications is a structural failure, and the overtly policy- and legally-oriented objects can lead to a recognition of politics' emergent locations and material forms. This would, of course, demand a more literate cohort of political scientists, requiring the ability to read a wide range of such objects. (Literacy in Native languages would also be a welcome bonus, albeit one currently outside the possibility of a social science dynamic which already underrecognizes non-English linguistic abilities.)

L. A reconfiguation of "local" research from its U.S. state-level assumptions to a regional and diachronic emphasis. Most universities and collegesespecially those in state systems-have a specialist in the politics of the state in which they are located, researchers focusing on (for example) the Georgia legislature and governor. This structure, while useful for providing quotable media analysis, obscures the real histories of place and space, unintentionally reinscribing a settler-colonial partitioning of land. A department committed to true regional scholarship would (instead or in addition) encourage scholarship on the realities of local and historical power and politics.

M. Undermining structures of individuation and encouraging relational research. Political science as a discipline is predicated upon a mode of liberal individualism dissociated from place. Take for example, two different answers to the question "Who are you and what do you do?" An academic answer concerns one's discipline and university; a Native reply would concern clan, language, and place. In the first the central aspect of one's identity is one's job and one's research; in the second, the central aspect is one's collective and kinship structure and relationship to land and non-human nature. The academy at large rewards the first and penalizes the second. These are (and should be) connected to extant criticisms of the academy's troubled relationship to gender, class, and race.

N. A critical stance toward majoritiarian democracy. Parallel to liberal individualism, the presumptions of majoritiarianism operate to delegitimize the particular and specific histories and relationships between governments and Native peoples. This is not to say that majority rule cannot work within recognized tribal governments - it can and does. It is instead to note that the constant refrain of democratic rule at the state and national level is used to malign tribal sovereignty, to legitimize past wrongs, and to ignore historical obligation. Political science, unknowingly or otherwise, instills and evokes settler logics to rationalize settlement through a celebration of the collective majority.

O. The embrace of a rich historicism as foundational to politics. Too often political scientists presume the primacy of theoretical, of political documents, and of ideological pronouncements. The colonization of the Americas, for example, is held to emerge from papal bulls and Lockean theories of land. But close attention to the ground, where colonial practices have always been pluralistic and have utilized ideology and law as a resource, not the primary source, for claimance, paints a far more complex picture.

P. Finally, a commitment to the presumption of democratic equality, where Native peoples and their interpretations of events and histories posess commensurate legitimacy to European narratives. Native peoples have co-created the American experience; an American political science must be remade to reflect this truth. Conflicts that exist between Native experiences and the dominant interpretations of U.S. political institutions, law, and nationhood must be explored and taught from all sides, presuming interpretive equivalence. Anything less is anti-egalitarian, anti-democratic, and anti-political.

\section{On Mixing}

I conclude with a story that emerged from my recent work on an encyclopedia of political thought. ${ }^{25}$ Early in the 
process, the editors agreed that certain terms are of great importance to political thought, and we accepted many (such as "democracy") without debate. In retrospect, it is interesting that all agreed on the importance of one entry: "metis." Only after the finished entries began to arrive many months later did we recognize a telling incommensurability in our discussion. For some of us, metis referred to the ancient Greek concept of wisdom in counsel, the ability to give and take advice for strategic and clever thinking. But others among us presumed we had been discussing the critical Canadian racial and cultural classification of métis: the descendants of mixed European and Native ancestry, who are legally recognized as one of Canada's three aboriginal groups.

The real question this misunderstanding raises is not which of these definitions (or, more properly, concepts) is more important to political theory. It is, instead, how none of us considered the possibility of confusion. Greek mythology was so distant to one group, and Native North American racial identity so unfamiliar to another, as to allow the surprisingly long-lived nature of this miscommunication. (The mistake emerged only when we asked a classicist to review an entry on Canadian racial classification. Needless to say, the confusion became clear immediately. Ultimately, we included both terms.) From the Native perspective, it is this particular absence of historical knowledge, this absence that Manu Vimalassery, Juliana $\mathrm{Hu}$ Pegues, and Alyosha Goldstein have called "colonial agnosia," which allows the continued complex existence of Native politics alongside uncomprehending and ignorant political modes of governmentality. ${ }^{26}$

The four observations - the absences of political scienceat the beginning of this essay are not causes but symptoms of such an agnosia in political science as a structured intellectual and academic discipline. They arise from centuries of state settler colonialism, culturally systematic racism, and disciplinary intellectual imperialism. Changing them, changing political science to embrace rather than reject Native power and lives, would affect only a small part of the problems American Indians face in the United States. Many of the historical and political consequences of the absence of Natives from political science, in their multitude of perspectives and ontological commitments, could never be repaired, and we will all remain impoverished by this long absence. But such a change would be a start.

\section{Notes}

1 A word on terminology. I use here a number of problematic terms, though not interchangeably, to refer to the people and nations who inhabited the lands now claimed by the United States, as well as their descendants. I use each of the most common terms, recognizing their insufficiency: "Indigene," though it implies a static and unchanging genetic identity; "Indian," though it is historical misnomer and often used in racist discourse; and "Native" (my preference), though it flattens forms of difference and hints at rhetorics of exclusion and nativism. In general, I attempt to use the terminology used by the specific author or interlocutor I am discussing, though at other times (as in the title) I use terms that make specific political claims.

2 Where is the data for these claims? The existence of any of these is too meager to even begin to quantify. Certainly some prelaw political science courses deal in small part with important Indian-United States cases, and a few political theory courses include an indigenous North American author. But as I will explain, the few data points that could be developed, such as the paucity of Native political scientists, are themselves understudied and undercounted. So I keep the following four claims general and incontrovertible.

3 Of course, political science as a discipline emerges from the Anglophone world, especially the United States, and remains centered in the United States in its current disciplinary formulation. See, e.g., American Political Science Association 1962; Ross 1993.

4 Deloria and Wilkins 1999.

5 Attempts had been made shortly before Deloria and Wilkins's writing, e.g., Wilmer, Melody, and Murdock 1994.

6 Deloria and Wilkins 1999, 73.

7 See, e.g. Seeley 1896, Ferguson 2014, and MacKenzie1976.

8 Vizenor 1999, vii.

9 See, for example, United Nations 2007.

10 Seliger 1968.

11 Some scholars have tried to change this, including many of those listed later in this essay. Also see Wadsworth 2014.

12 In the 1980s, a number of historians angrily debated what became known as the "influence thesis": the idea that the relationship between individual states and the larger United States was based in part on the practices of the Five Nations Confederacy. Primary in this effort were Grinde and Johansen 1991. For a dissenting reading, see Tooker 1988.

13 See, for example, Miller 2010.

14 Compare this to the willingness (and commitment) of departments to hire faculty whose specialty in state and local politics has meant that they have been trained nearby or at the very institution where they are being hired.

15 Leigh Jenco 2015 convincingly argues for CPT to engage in "cultural learning" rather than "translation," but her point can be pushed further. See also Chakrabarty 2000 and Santos 2012.

16 Because I hope the discipline would still be recognizable, these suggestions are limited to the transformations that could take place within political science. To fully indigenize it, however, would require questioning 
a number of foundational assumptions, for example the distinctions between the human and other kinds of living beings, the divisibility of self from land and place, and the unidirectional and separable nature of time. Small steps first.

17 http://www.state.gov/documents/organization/ 218912.pdf

18 This number applies to the continental United States. Including Alaska, the number is 566. See the United States Federal Register 2015. (And these are only the recognized tribal entities; native Hawaiians are not included, nor are groups of Natives who for various reasons have never sought recognition or have been denied it.)

19 See Vizenor and Doerfler 2012; also Brooks 2011.

20 An introductory sample, though each wrote extensively includes Occam 2006; O'Connell 1992; Bonnin 1924; Eastman 1911; Deloria 1969.

21 Alfred 2005; Turner 2006; Byrd 2011; Coulthard 2014.

22 See Wilkins 1997 and Deloria and Wilkins 2000, among many others.

23 Vizenor 1999; Simpson 2014; Barker 2011.

24 Bruyneel, 2007; Goldstein 2014.

25 Gibbons et al. 2014.

26 Vimalassery et al. 2016.

\section{References}

Alfred, Gerald Taiaiake. 2005. Wasáse: Indigenous Pathways of Action and Freedom. Toronto: University of Toronto Press.

American Political Science Association, Committee on Standards of Instruction. 1962. "Political Science as a Discipline." American Political Science Review 56(2): 417-21.

Barker, Joanne. 2011. Native Acts: Law, Recognition, and Cultural Authenticity. Durham: Duke University Press.

Bonnin, Gertrude (Zitkala-Sa). 1924. Oklahoma's Poor Rich Indians: An Orgy of Graft and Exploitation of the Five Civilized Tribes, Legalized Robbery. Philadelphia: Office of the Indian Rights Association.

Brooks, Lisa. 2011. "The Constitution of the White Earth Nation: A New Innovation in a Longstanding Indigenous Literary Tradition." Studies in American Indian Literatures 23(4): 48-76.

Bruyneel, Kevin. 2007. The Third Space of Sovereignty: The Postcolonial Politics of U.S.-Indigenous Relations. Minneapolis: University of Minnesota Press.

Byrd, Jodi. 2011. The Transit of Empire: Indigenous Critiques of Colonialism. Minneapolis: University of Minnesota Press.

Chakrabarty, Dipesh. 2000. Provincializing Europe: Postcolonial Thought and Historical Difference. Princeton, NJ: Princeton University Press.

Coulthard, Glen. 2014. Red Skin, White Masks: Rejecting the Colonial Politics of Recognition. Minneapolis: University of Minnesota Press.
Deloria, Vine Jr. 1969. Custer Died for Your Sins: An Indian Manifesto. Norman: University of Oklahoma Press.

Deloria, Vine Jr. and David E. Wilkins. 1999. "Racial and Ethnic Studies, Political Science, and Midwifery." Wicazo Sa Review 14(2): 70.

- 2000. Tribes, Treaties, and Constitutional Tribulations. Austin: University of Texas Press.

Eastman, Charles. 1911. The Soul of the Indian: An Interpretation. New York: Houghton.

Ferguson, Kennan. 2014. "The Deep Biology of Politics: A Reminder." Political Research Quarterly 67(2): 457-61.

Gibbons, Michael T., Diana Coole, Elisabeth Ellis, and Kennan Ferguson, eds. 2014. The Encyclopedia of Political Thought, 8 vols. New York: Wiley Blackwell.

Goldstein, Alyosha. 2014. Formations of United States Colonialism. Durham: Duke University Press.

Grinde, Donald A. Jr. and Bruce E. Johansen. 1991. Exemplar of Liberty: Native America and the Evolution of Democracy. Native American Studies Series. Los Angeles: UCLA.

Jenco, Leigh. 2015. Changing Referents: Learning Across Space and Time in China and the West. Oxford: Oxford University Press.

MacKenzie, Donald. 1976. "Eugenics in Britain.” Social Studies of Science 6(3/4): 499-532.

Miller, Cary. 2010. Ogimaag: Anishinaabeg Leadership, 1760-1845. Lincoln: University of Nebraska Press.

Occam, Sampson. 2006. The Collected Writings of Samson Occom, Mohegan. Ed. Joanna Brooks. Literature and Leadership in Eighteenth-Century Native America. Oxford: Oxford University Press.

O'Connell, Barry, ed. 1992. On Our Own Ground: The Complete Writings of William Apess, a Pequot. Amherst: University of Massachusetts Press.

Ross, Dorothy. 1993. "The Development of the Social Sciences." In Discipline and History: Political Science in the United States, ed. James Farr and Raymond Seidelman. Ann Arbor: University of Michigan Press.

Seeley, Sir John Robert. 1896. Introduction to Political Science: Two Series of Lectures. London: Macmillan.

Seliger, Martin. 1968. The Liberal Politics of John Locke. New York: Frederick A.

Simpson, Audra. 2014. Mohawk Interruptus: Political Life across the Borders of Settler States. Durham: Duke University Press.

Santos, Boaventura de Sousa. 2012. "Public Sphere and Epistemologies of the South" Africa Development 37(1): 43-67.

Tooker, Elisabeth. 1988. "The United States Constitution and the Iroquois League." Ethnohistory 35(4): 305-36.

Turner, Dale. 2006. This Is Not a Peace Pipe: Towards a Critical Indigenous Philosophy. Toronto: University of Toronto Press.

United, Nations. 2007. United Nations Declaration on the Rights of Indigenous Peoples. New York: United Nations. 
United States Federal Register. 2015. January 14: 80(9): $1942-48$.

Vimalassery, Manu, Juliana Hu Pegues, and Alyosha Goldstein. 2016. "On Colonial Unknowing." Theory \& Event 19(4).

Vizenor, Gerald. 1999. Manifest Manners: Narratives on Postindian Survivance. Lincoln: Nebraska.

Vizenor, Gerald and Jill Doerfler, eds. 2012. The White Earth Nation: Ratification of a Native Democratic

Constitution. Lincoln: University of Nebraska Press.
Wadsworth, Nancy. 2014. "Unsettling Lessons: Teaching Indigenous Politics and Settler Colonialism in Political Science." PS: Political Science \&o Politics 47(3): 692-69. Wilkins, David E. 1997. American Indian Sovereignty and the U.S. Supreme Court: The Masking of Justice. Austin: University of Texas Press.

Wilmer, Franke, Michael E. Melody, and Margaret Maier Murdock. 1994. "Including Native American Perspectives in the Political Science Curriculum." PS: Political Science and Politics 27(2): 269-76. 